\title{
Comparative Analysis of Spontaneous and Stimulus-Evoked Calcium Transients in Proliferating and Differentiating Human Midbrain-Derived Stem Cells
}

\author{
Torben Johansen, ${ }^{1}$ Christina Krabbe, ${ }^{2}$ Sissel Ida Schmidt, ${ }^{2}$ Alberto Martínez Serrano, ${ }^{3}$ and \\ Morten Meyer ${ }^{2}$ \\ ${ }^{1}$ Department of Cardiovascular and Renal Research, University of Southern Denmark, J.B.Winsløws Vej 21, \\ 5000 Odense C, Denmark \\ ${ }^{2}$ Department of Neurobiology Research, Institute of Molecular Medicine, University of Southern Denmark, J.B.Winsløws Vej 21, \\ 5000 Odense C, Denmark \\ ${ }^{3}$ Department of Molecular Biology and Center of Molecular Biology Severo Ochoa, UAM-CSIC, Campus Cantoblanco, \\ 28049 Madrid, Spain
}

Correspondence should be addressed to Morten Meyer; mmeyer@health.sdu.dk

Received 30 June 2017; Accepted 10 September 2017; Published 22 October 2017

Academic Editor: Luca Vanella

Copyright (c) 2017 Torben Johansen et al. This is an open access article distributed under the Creative Commons Attribution License, which permits unrestricted use, distribution, and reproduction in any medium, provided the original work is properly cited.

\begin{abstract}
Spontaneous cytosolic calcium transients and oscillations have been reported in various tissues of nonhuman and human origin but not in human midbrain-derived stem cells. Using confocal microfluorimetry, we studied spontaneous calcium transients and calcium-regulating mechanisms in a human ventral mesencephalic stem cell line undergoing proliferation and neuronal differentiation. Spontaneous calcium transients were detected in a large fraction of both proliferating $(>50 \%)$ and differentiating $(>55 \%)$ cells. We provide evidence for the existence of intracellular calcium stores that respond to muscarinic activation of the cells, having sensitivity for ryanodine and thapsigargin possibly reflecting $\mathrm{IP}_{3}$ receptor activity and the presence of ryanodine receptors and calcium ATPase pumps. The observed calcium transient activity potentially supports the existence of a sodiumcalcium antiporter and the existence of calcium influx induced by depletion of calcium stores. We conclude that the cells have developed the most important mechanisms governing cytosolic calcium homeostasis. This is the first comparative report of spontaneous calcium transients in proliferating and differentiating human midbrain-derived stem cells that provides evidence for the mechanisms that are likely to be involved. We propose that the observed spontaneous calcium transients may contribute to mechanisms involved in cell proliferation, phenotypic differentiation, and general cell maturation.
\end{abstract}

\section{Introduction}

Calcium is a versatile intracellular messenger controlling a wide range of cellular processes [1-3] including cell proliferation, cell differentiation, and general gene transcription [4-7]. Calcium signals are considered to be involved in fertilization of most species [8-11] as well as in the subsequent embryonic development [12-18].

Spontaneous calcium transients and oscillations have been reported in a number of tissues of nonhuman origin [19]. More recently, spontaneous calcium oscillations have been observed in early postnatal cerebellar Purkinje neurons [20], embryonic mouse cortical brain slices [21], mouse spinal cord neurons [22], slice cultures of the spinal cord and dorsal root ganglia prepared from mouse embryos [23], and undifferentiated cells and neural progenitor cells derived from a mouse bone marrow [24]. There have also been reports on spontaneous calcium oscillations in human mesenchymal stem cells [25-27], human embryonic stem cellderived neurons [28], and human cardiac progenitor cells [29]. It appeared that calcium supply to cytosol was derived from intracellular calcium stores by $\mathrm{IP}_{3}$-dependent release 
and influx of calcium through store-operated channels. Removal of calcium was dependent on plasma membrane calcium pump activity and $\mathrm{Na}^{+}-\mathrm{Ca}^{2+}$ exchange [25-27].

It has been reported that the mechanisms that regulate spontaneous calcium oscillations in stem cells may change during their transition from proliferation to differentiation and maturation [27, 30-33]. However, no reports describe changes in calcium regulation specifically in human midbrain-derived stem cells during their development to neurons.

The present investigation was initially performed in order to study spontaneous calcium signaling in human midbrain-derived stem cells undergoing neuronal differentiation [34-37]. Since we observed spontaneous calcium transients in a large fraction of the differentiating cells, it was of interest to further explore the development of calcium-regulating mechanisms by comparing the mechanisms in differentiating cells with mechanisms operating in proliferating cells.

Using a confocal imaging technique, we here provide evidence for the existence of intracellular calcium stores that respond to muscarinic activation, having sensitivity to ryanodine and thapsigargin possibly reflecting $\mathrm{IP}_{3}$ receptor activity and the presence of ryanodine receptors and calcium ATPase pumps. The observed calcium transient activity may support the existence of a sodium-calcium antiporter and the existence of calcium influx induced by depletion of calcium stores.

We conclude that identical calcium-regulating mechanisms operate during the proliferation and neuronal differentiation of human midbrain-derived stem cells.

\section{Materials and Methods}

2.1. Ethics Statement. Human tissues were donated for research after written informed consent of women seeking abortion was provided. Tissue procurement was performed in accordance with the Declaration of Helsinki and in agreement with the ethical guidelines of the Network of European CNS Transplantation and Restoration (NECTAR). Approval to use these tissues for research was granted by the Lund University Hospital Ethical Committee, and their use was in compliance with Spanish law 35/1988 on Assisted Reproduction. Ethics statements about the human fetal origin of the cells used in the present study can be found in the original report describing the cell line [37].

2.2. Culturing and Passaging of Human Midbrain-Derived Stem Cells. Cell isolation, genetic modifications, and general characterizations are described elsewhere [34-37]. Briefly, cells were isolated from the ventral mesencephalon of a 10 -week-old human fetus. Immortalization was carried out by infection with a retroviral vector coding for v-myc. Derivatives of the resulting cell line (hVM1 cells) were used for stable retroviral overexpression of $\mathrm{Bcl}-\mathrm{X}_{\mathrm{L}}$, essentially as described by Liste et al. [38]. After infection, the cells were selected by GFP-based fluorescent-activated cell sorting, resulting in the cell line hVMbcl- $\mathrm{x}_{\mathrm{L}}$ [34-36] used in the present study.
Cells at passage 20 were plated onto poly-L-lysine- (PLL; Sigma-Aldrich, St. Louis, MO, USA) coated T75 culture flasks containing a $15 \mathrm{ml}$ HNSC100 culture medium (DMEM/F12 with Glutamax (Gibco, Rockville, MD, USA), $0.6 \%(w / v)$ D-glucose (Sigma-Aldrich), $0.5 \%(v / v) 1 \mathrm{M}$ Hepes (Gibco), 0.5\% (w/v) AlbuMAX-I (Gibco), 1\% (v/v) N2 supplement (Gibco), $1 \%(v / v)$ NEAA (Sigma-Aldrich), and $1 \%$ Pen/Strep (Gibco)) supplemented with $20 \mathrm{ng} / \mathrm{ml}$ recombinant human epidermal growth factor (EGF, R\&D Systems) and $20 \mathrm{ng} / \mathrm{ml}$ recombinant human basic fibroblast growth factor (bFGF, R\&D Systems). Cells were propagated at $36^{\circ} \mathrm{C}$ in a controlled atmosphere of $5 \% \mathrm{CO}_{2}$ and $95 \%$ humidified air. The medium was changed every third day, and cells passaged at $80 \%$ confluence. For passaging, adherent cells were washed with phosphate buffered saline (PBS) without calcium and magnesium, before detachment by trypsin-EDTA (Gibco) diluted $1: 10$ in PBS for $3-5 \mathrm{~min}$ at $36^{\circ} \mathrm{C}$. Trypsinized cells were resuspended, centrifuged for $5 \mathrm{~min}$ at $4^{\circ} \mathrm{C}(130 \mathrm{~g})$, and plated in new flasks.

2.3. Neuronal Differentiation Protocol. Stem cells were differentiated into neurons $(>90 \%)$ using the CK4 protocol $[34,35]$. In brief, cells were plated in PLL-coated 24-well culture trays (Nunc) at a density of $5000 \mathrm{cells} / \mathrm{cm}^{2}$ in a HNSC100 medium with sequential addition of $50 \mathrm{ng} / \mathrm{ml}$ recombinant fibroblast growth factor 8 (R\&D Systems), $25 \mu \mathrm{M}$ forskolin (Sigma-Aldrich), $5 \mathrm{ng} / \mathrm{ml}$ recombinant glial cell line-derived neurotrophic factor (Promega, Madison, WI, USA), and $25 \mathrm{ng} / \mathrm{ml}$ recombinant sonic hedgehog (R\&D Systems). Cells for fluorescence staining were grown on $14 \mathrm{~mm}$ PLL-coated glass coverslips. Cells were differentiated for 10 days at $36^{\circ} \mathrm{C}$ in controlled atmosphere of $5 \%$ $\mathrm{CO}_{2}$ and $95 \%$ humidified air, with half of the medium being changed every third day.

2.4. Cell Fixation and Immunocytochemistry. Cells were fixed in $4 \%$ paraformaldehyde in $0.15 \mathrm{M}$ PBS, $\mathrm{pH} 7.4$ for $20 \mathrm{~min}$ and then rinsed for $3 \times 15 \mathrm{~min}$ in $0.05 \mathrm{M}$ Tris buffered saline (TBS, pH 7.4)/0.1\% Triton X-100 (Sigma-Aldrich). Cultures were then preincubated for $30 \mathrm{~min}$ in $\mathrm{TBS} / 10 \%$ donkey (Millipore) or sheep serum (Sigma-Aldrich) before incubation with one of the following primary antibodies in TBS/ $10 \%$ donkey or sheep serum for $24 \mathrm{~h}$ at $4^{\circ} \mathrm{C}$ : beta-tubulin III ( $\beta$-tub III, monoclonal mouse; Sigma-Aldrich) 1:2000; tyrosine hydroxylase (TH, polyclonal rabbit; Chemicon) $1: 1200 ; \gamma$-aminobutyric acid (GABA, polyclonal antirabbit; Sigma-Aldrich) 1:500; microtubule-associated protein 2ab (Map2, monoclonal anti-mouse; Sigma-Aldrich) 1:2000; glial fibrillary acidic protein (GFAP, polyclonal anti-rabbit; DAKO, Carpenteria, CA, USA) 1:5000; doublecortin (DCX, polyclonal guinea anti-pig; Chemicon) 1:400; human nuclei (HN, monoclonal anti-mouse; Chemicon) 1:500; nestin (anti-human; AbD Serotec) 1:2000; and Ki67 (polyclonal anti-rabbit; Neomarkers Inc.) 1:500. Control stainings were performed by excluding primary antibodies or using IgG rabbit (DAKO) $1: 20,000$ and $\operatorname{IgG}_{1}$ mouse (DAKO) $1: 200$.

Cultures were rinsed for $3 \times 15 \mathrm{~min}$ in TBS/0.1\% Triton$\mathrm{X}-100$ and then incubated for $1 \mathrm{~h}$ with one of the following 
biotinylated secondary antibodies in TBS/10\% donkey or sheep serum: anti-guinea pig Ig (Jackson ImmunoReseach) 1:200, anti-rabbit Ig $1: 200$ or anti-mouse Ig 1:200 (Amersham). Cells were rinsed for $3 \times 15 \mathrm{~min}$ in TBS $/ 0.1 \%$ Triton X-100 and incubated for $60 \mathrm{~min}$ with horseradish peroxidase- (HRP-) conjugated streptavidin (DAKO) diluted $1: 200$ in TBS/10\% donkey or sheep serum. Cultures were then rinsed for $3 \times 15 \mathrm{~min}$ in TBS before visualization with $3.3^{\prime}$-diaminobenzidine $\left(50 \mathrm{mg} 3.3^{\prime}\right.$-diaminobenzidine (Sigma-Aldrich) and $33 \mu \mathrm{H}_{2} \mathrm{O}_{2}$ per $100 \mathrm{ml}$ TBS for 5$10 \mathrm{~min}$ ). After rinsing for $15 \mathrm{~min}$ in TBS and briefly in distilled water, cultures were coverslipped in Aquatex (VWR).

Immunofluorescence staining of proliferating cell cultures was also performed. In brief, cultures were rinsed for $3 \times 15 \mathrm{~min}$ in TBS/0.1\% Triton X-100 and then preincubated for $30 \mathrm{~min}$ in $\mathrm{TBS} / 5 \%$ goat serum (Chemicon) and then incubated for $24 \mathrm{~h}$ at $4{ }^{\circ} \mathrm{C}$ with the following primary antibodies diluted in TBS/5\% goat serum: $\mathrm{HN}$ (monoclonal antimouse; Chemicon) 1:500; nestin (polyclonal anti-rabbit; Abcam) 1:1000; and $\beta$-tub III (monoclonal anti-mouse; Sigma-Aldrich) 1:2000; Ki67 (polyclonal anti-rabbit; Neomarkers Inc.) 1:500. Subsequently, cells were washed for $3 \times 15 \mathrm{~min}$ in TBS $/ 0.1 \%$ Triton X-100 and incubated with Alexa Flour ${ }^{\circledR 555}$-conjugated mouse IgG and Alexa ${ }^{\circledR} 488$ antirabbit IgG for two hours. Plates were washed for $2 \times 15 \mathrm{~min}$ in TBS and $1 \times 15$ min in TBS added $4^{\prime}$-6-diamidino-2-phenylindole (DAPI; Sigma-Aldrich) for general staining of cell nuclei. After a brief wash in distilled water, cells on coverslips were mounted with ProLong Gold (Molecular Probes, Grand Island, NY, USA) onto glass slides. Confocal pictures were taken using FluoView FV1000MPE -Multiphoton Laser Scanning Microscope (Olympus, Hamburg, Germany).

2.5. Measurements of Intracellular Calcium. Monolayers of stem cells proliferated for 2 days or differentiated for 10 days on PLL-coated glass coverslips were loaded with $5 \mu \mathrm{M}$ Fura2/AM (acetoxymethyl ester of fura-2; Molecular Probes) or Fluo-4-AM (see below) for $30 \mathrm{~min}$ at room temperature in the dark. Extracellular dye was removed by repeated dilution of the sample in Krebs-Ringer solution. Then, the cells were incubated in a buffered salt solution appropriate for the experiments, that is, containing various concentrations of calcium or calcium free with or without EGTA added. For some experiments, addition of $2 \mu \mathrm{M}$ thapsigargin (Molecular Probes) to the calcium-free loading solution was used in order to deplete intracellular calcium stores.

The intracellular $\mathrm{Ca}^{2+}$ concentration was monitored using confocal microscopy (inverted epifluorescence microscope; Zeiss Axiovert 35) and a $\mathrm{Ca}^{2+}$ image system (TILL Photonics $\mathrm{GmbH}$ ). Fura-2 was excited at $360 \mathrm{~nm}$ and $380 \mathrm{~nm}$. Emission was measured at $510 \mathrm{~nm}$ through a long pass filter. Images were collected at a frame rate of $0.33 \mathrm{~Hz}$. TILLVision software (TILL Photonics $\mathrm{GmbH}$ ) was used to generate ratio images and to analyze individual cell fluorescence intensity by use of region of interest (ROI). Intracellular calcium $\left(\left[\mathrm{Ca}^{2+}\right]_{\mathrm{i}}\right)$ is expressed as a ratio of fluorescence emission caused by excitation at $360 \mathrm{~nm}$ and $380 \mathrm{~nm}$ (excitation ratio $\left.360 / 380\left(\mathrm{~F}_{360} / \mathrm{F}_{380}\right)\right)$. The performance of the image system was tested by external calibration using a calibration kit (Molecular Probes) (free $\mathrm{Ca}^{2+}$ concentration from $0 \mu \mathrm{M}$ to $39 \mu \mathrm{M})$. The average isosbestic point was $363 \mathrm{~nm}$, and we found an almost linear relation between $\left[\mathrm{Ca}^{2+}\right]$ and the fluorescence intensity (excitation ratio 360/380) from $17 \mathrm{nM}$ to $1.35 \mu \mathrm{M}$ of $\left[\mathrm{Ca}^{2+}\right]$. Fura-2-loaded cells were used to visualize the spontaneous transients in differentiated stem cells. Intracellular calcium in proliferating stem cells was measured using Fluo-4-loaded cells. Fluorescence measurements were performed using a FluoView FV1000MPE multiphoton laser scanning microscope (Olympus). Fluo-4 was excited at $488 \mathrm{~nm}$. Emission was measured at $510 \mathrm{~nm}$ through a long pass filter. Images were collected at a rate of $0.45 \mathrm{~Hz}$.

2.6. Chemicals. Fura-2-AM, Fluo-4-AM, thapsigargin, and Ryanodine Calibration kit were supplied by Molecular Probes. All other chemicals were purchased from SigmaAldrich and Merck.

Krebs-Ringer solution (in $\mathrm{mM}$ ): $\mathrm{NaCl}, 139 ; \mathrm{KCl}, 5$; $\mathrm{MgCl}_{2}, 1.2 ; \mathrm{CaCl}_{2}, 2$; glucose, 10 ; HEPES, $10 \mathrm{pH}$ was adjusted to 7.4 by $\mathrm{NaOH}$. N-methyl-D-glucosamine (NMDG) replaced sodium in sodium-free solutions.

2.7. Data Analysis and Statistics. Data are reported as mean and SEM. Student's $t$-test was used for statistical comparisons of unpaired groups. A $p$ value lower than 0.05 was considered statistically significant.

\section{Results}

3.1. General Immunocytochemical Characterization of Proliferating Stem Cells and Differentiating Derivatives. To study spontaneous calcium transients in human neurons, we used a well-characterized human ventral mesencephalic stem cell line $[34,35,37]$. Prior to analysis of calcium transients, cells were differentiated for 10 days in vitro according to our neuronal differentiation protocol (CK4 protocol) in which fibroblast growth factor $8(50 \mathrm{ng} / \mathrm{ml})$, forskolin $(25 \mu \mathrm{M})$, glial cell line-derived neurotrophic factor $(5 \mathrm{ng} / \mathrm{ml})$, and sonic hedgehog $(25 \mathrm{ng} / \mathrm{ml})$ are added in a sequential manner $[34,35]$.

For initial general cytological characterization and quality control, cells were either propagated in the presence of epidermal growth factor (EGF, $20 \mathrm{ng} / \mathrm{ml}$ ) and basic fibroblast growth factor (bFGF, $20 \mathrm{ng} / \mathrm{ml}$ ) for 4 days or differentiated for 10 days as described above. Cells were then immunostained for markers of dividing cells, neural progenitor cells, newly generated neurons, mature neurons, astroglial cells, and specific neuronal subtypes (Figure 1).

To investigate the proliferative capacity in propagating cultures, cells were immunostained for Ki67. At day 4 of propagation, almost all cells were in different phases of cell division (Figure 1(a)), and they expressed the intermediate filament nestin (Figure 1(b)), which is a general marker of neural precursor cells. In propagating cultures, only few cells had started to differentiate into neurons as shown by the presence of very few $\beta$-tubulin III- ( $\beta$-tub III-) positive cells, a marker of newly generated neurons (Figure 1(c)).

In 10-day-old differentiating cultures, several cells were found to express doublecortin (DCX) (Figure 1(d)), a 


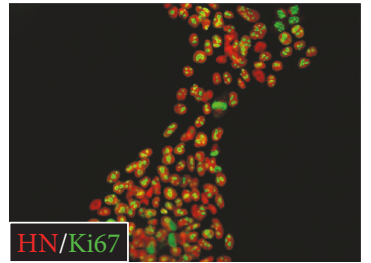

(a)

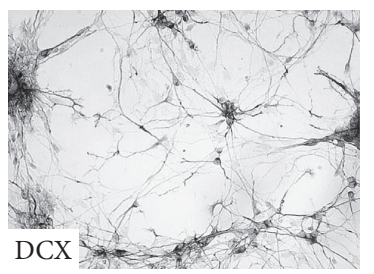

(d)

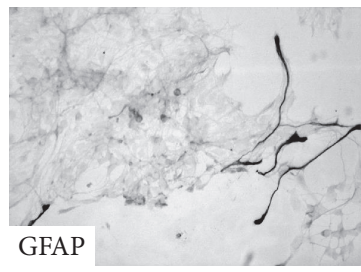

(g)

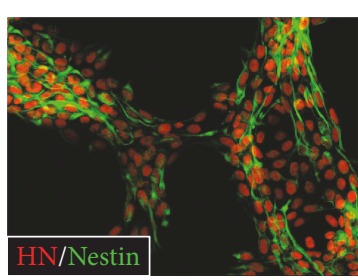

(b)

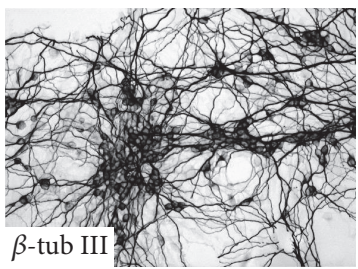

(e)

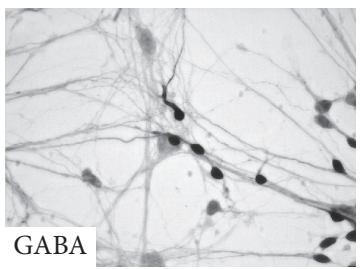

(h)

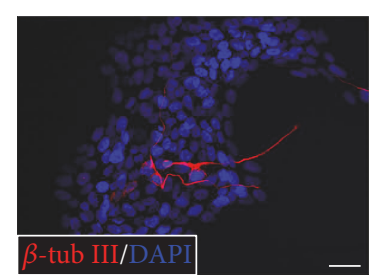

(c)

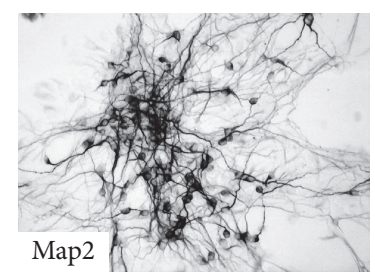

(f)

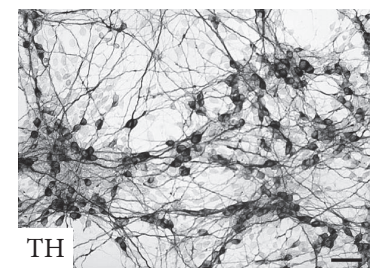

(i)

FIGURE 1: Immunocytochemical characterization of proliferating ( $a, b, c)$ and differentiating human midbrain-derived stem cells (d, e, f, g, h, i). Immunofluorescence staining of cultures propagated for 4 days by exposure to epidermal growth factor and basic fibroblast growth factor was performed. Almost all cells expressed Ki67, a marker of dividing cells (a). Moreover, a large proportion of the cells expressed the intermediate filament protein nestin, a marker of neural progenitor cells (b). Only very few cells had spontaneously differentiated into $\beta$-tubulin III- ( $\beta$-tub III-) positive neurons (c). Cells were differentiated for 10 days by exposure to fibroblast growth factor 8 for three days followed by exposure to forskolin, sonic hedgehog, and glial cell line-derived neurotrophic factor for seven days and immunostained for neuronal and astroglial markers. At this time point, some cells expressed the early marker of migrating neuronal cell doublecortin $(\mathrm{DCX})(\mathrm{d})$, whereas extensive staining for another early neuronal marker, $\beta$-tub III (e), and a mature neuronal marker, microtubule-associated protein 2ab (Map2) (f), was seen. A large proportion of cells expressed tyrosine hydroxylase (TH), a marker of catecholaminergic neurons (i), whereas only few cells were found to express $\gamma$-aminobutyric acid (GABA), a marker for GABAergic neurons (h). Very few cells were found to express glial fibrillary acidic protein (GFAP), a marker of astroglial cells (g). Scale bars $=50 \mu \mathrm{m}$.

microtubule-associated protein expressed in migrating and developing neurons that is downregulated in fully differentiated cells. Numerous $\beta$-tub III-positive neurons (Figure 1(e)) and microtubule-associated protein 2- (MAP2-) positive mature neurons were found in all differentiating cultures (Figure 1(f)). In contrast, only few cells stained positive for the astroglial marker glial fibrillary acidic protein (GFAP) (Figure 1(g)). Cells were also immunostained for markers of more specific neuronal subtypes. Numerous cells were found to express tyrosine hydroxylase (TH), a marker of catecholaminergic neurons (Figure 1(i)), whereas only few cells expressed a marker of GABAergic neurons (GABA) (Figure 1(h)).

Taken together, all stem cell cultures were viable and displayed a healthy appearance, and after differentiation, they were highly rich in neuronal cells (>90\% of total cells).

\subsection{Differentiating Midbrain-Derived Stem Cells}

3.2.1. Calcium Supply to Spontaneous Calcium Transients in Cytosol of Differentiating Neurons. Spontaneous calcium transients were observed in $51 \%$ of the differentiating cells
(Figures 2(a), 2(b), and 2(d); Supplemental Figure 1, video available online at https://doi.org/10.1155/2017/9605432). Removal of extracellular calcium as well as depletion of the intracellular calcium stores significantly reduced the fraction of cell with spontaneous calcium transients $(p<0.05)$. Depletion of the intracellular calcium stores was performed by exposure of the cells to $2 \mu \mathrm{M}$ thapsigargin in a calcium-free medium for $30 \mathrm{~min}$ before the experiments. The fraction of cells with spontaneous calcium transients was also significantly reduced by addition of $2 \mu \mathrm{M}$ thapsigargin to the cells even in the presence of extracellular calcium $(p<0.05)$. In contrast, incubation of the cells in the presence of $10 \mu \mathrm{M}$ ryanodine that binds to the ryanodine receptor in the endoplasmic reticulum $[39,40]$, significantly increased $(p<0.05)$ the fraction of cells with calcium transients. There were no calcium transients in store-depleted cells when incubated in a calcium-free medium (three independent control experiments, not shown).

The number of calcium transients during $20 \mathrm{~min}$ incubation in each differentiating cell was calculated (Figure 2(c)). A calcium transient was defined as a peak of 0.05 fluorescence units or more over baseline. We observed 3.38 (mean value) 


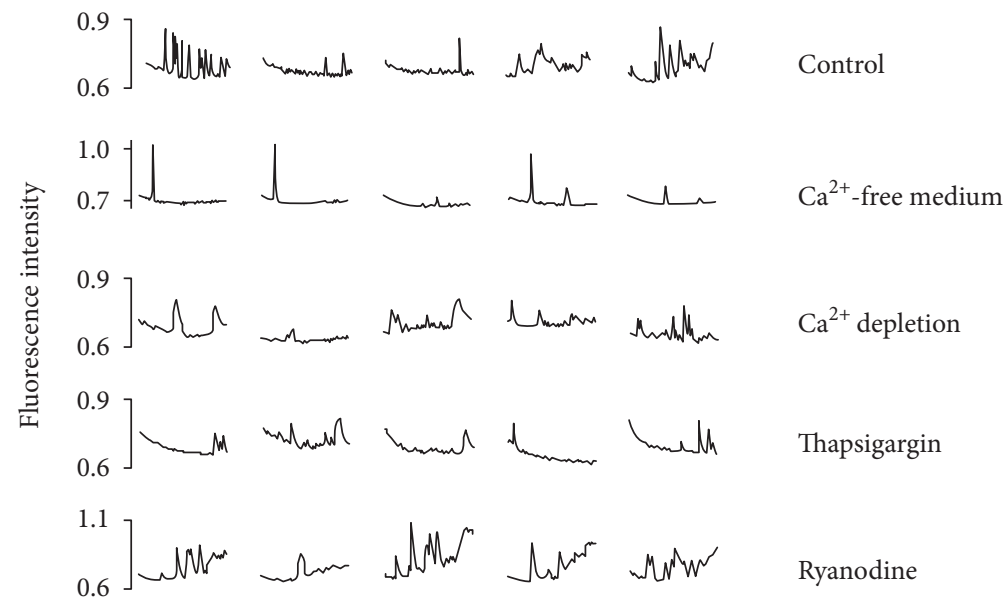

(a)

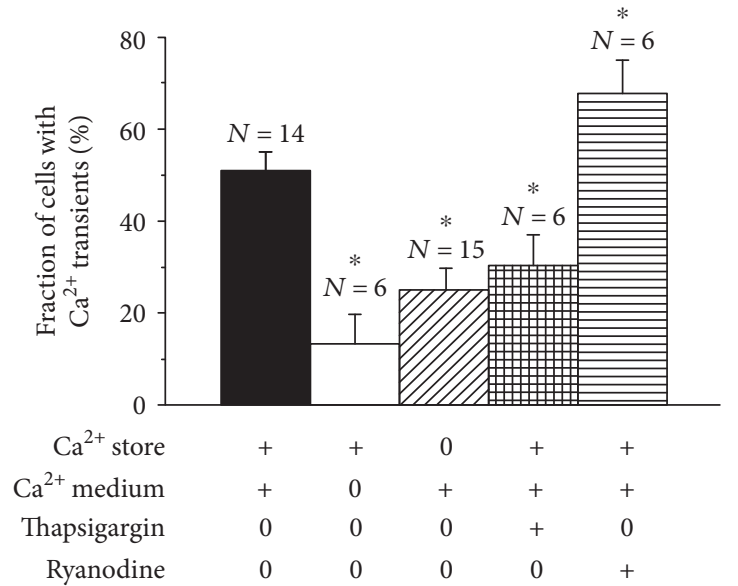

(b)

Time-lapse images
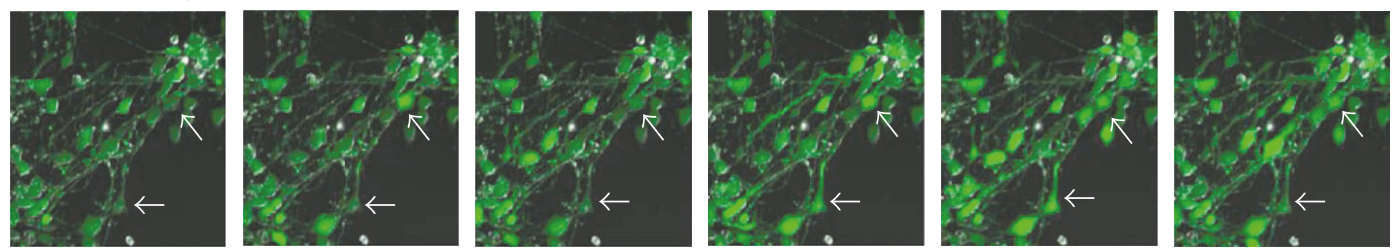

(d)

FIgURE 2: Spontaneous calcium transients in cytosol of differentiating stem cells are dependent on intracellular and extracellular calcium supply. Fura-2-loaded cells were measured for $20 \mathrm{~min}$ at room temperature. The pattern of calcium transients from five representative cells is shown (a). The fraction of cells with calcium transients (cytosolic calcium increase followed by decrease) was calculated in each experiment (b), as was the number of transients per cell (c). The cells were incubated in the presence or absence of extracellular calcium as indicated on the figure. Pretreatment with thapsigargin in the absence of calcium was used to deplete the intracellular calcium stores (third bars in the two histograms). Ryanodine was used to study the role of ryanodine receptors. The mean values and SEM from 6-15 independent experiments (b) and 40-378 cells (c) are shown. * indicate significant difference from the control value. Consecutive recordings (still images) of Fluo-4-loaded cells with a $60 \mathrm{sec}$ interval ((d); corresponding video available, see Supplemental Figure 1).

transients in the fraction of cells showing spontaneous calcium transients and intact calcium stores, when the cells were incubated in a calcium-containing medium. The number of transients per cell was significantly reduced if the cells were incubated in a calcium-free medium ( 1.88 transients per cell) as well as if the cellular calcium stores were depleted by preincubation of the cells with $2 \mu \mathrm{M}$ thapsigargin, even when calcium was present during the incubation period (1.98 transients per cell) $(p<0.05)$. When $2 \mu \mathrm{M}$ thapsigargin was added to the cells, even in presence of extracellular calcium, the number of transients per cell was also reduced $(2.43$ transients per cell) $(p<0.05)$. However, by incubation of the cells with $10 \mu \mathrm{M}$ ryanodine, the number of transients per cell (3.04 transients) was similar to the 


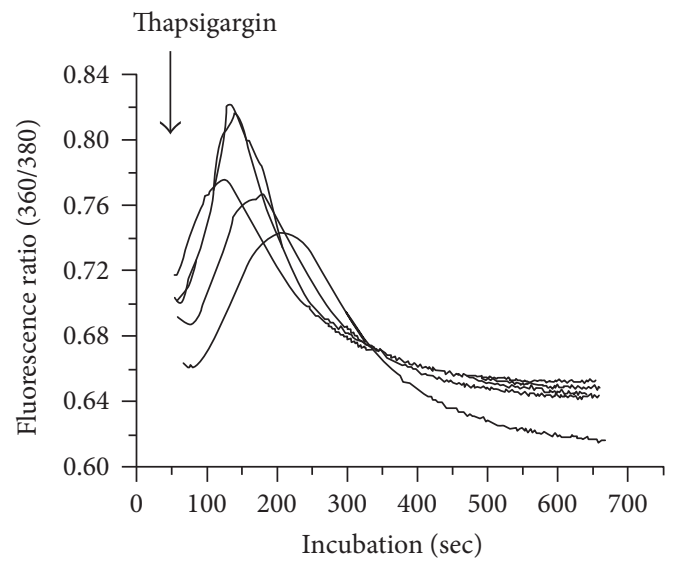

(a)

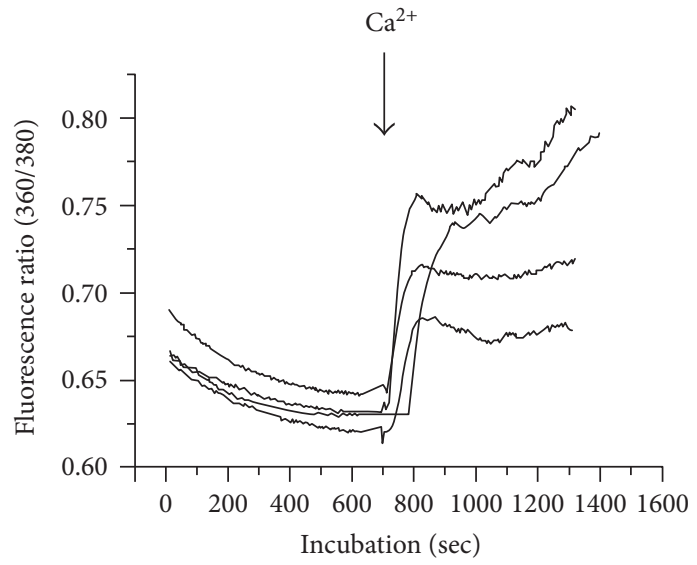

(b)

FIGURE 3: Effects of thapsigargin on cytosolic calcium (a) and calcium addition to store-depleted differentiating stem cells (b). Cells were incubated in a calcium-free medium with $10 \mu \mathrm{M}$ EGTA and then $2 \mu \mathrm{M}$ thapsigargin was added (arrow). The cells were dye loaded in Krebs-Ringer solution (containing $2 \mathrm{mM}$ calcium). The results from five independent experiments are shown, each represents the mean value from 29 to 65 cells, all of which with a calcium transient in response to thapsigargin (a). The cells were dye loaded in the presence of calcium and thapsigargin $(2 \mu \mathrm{M})$. The dye was removed and the cells were primed with $2 \mu \mathrm{M}$ thapsigargin for 12 min in calcium-free solution. Then $2 \mathrm{mM}$ calcium was added, and the incubation lasted for 8-11 min. The results from four independent experiments are shown, each representing the mean value obtained from analysis of 23 to 39 cells, all of which displayed calcium transients in response to the addition of calcium (b).

value observed for cells with intact calcium stores when incubated in a calcium-containing medium.

\subsubsection{Pattern of Cytosolic Calcium Transients in} Differentiating Neurons. While the appearance of the spontaneous transients (Figure 2(a)) varied a lot in frequency and peak size in cells with intact calcium stores and exposed to extracellular calcium, only a few narrow peaks appeared regularly when extracellular calcium was omitted. The appearance of small but broad peaks was the result of calcium depletion. The resting level of cytosolic calcium between the peaks was not changed in these cells. In contrast, baseline calcium decreased gradually with time in thapsigargin-treated cells and increased gradually in ryanodine-treated cells. The transients tended to appear at the end of the observation period in thapsigargin-treated cells. In ryanodine-treated cells, there were many transients of various sizes.

3.2.3. Effect of Thapsigargin on Cytosolic Calcium in Differentiating Neurons and Effect of Calcium Addition on Thapsigargin-Primed Cells. Exposure of the differentiating cells to $2 \mu \mathrm{M}$ thapsigargin induced a transient increase of cytosolic calcium in all the cells assessed in the five independent experiments (Figure 3(a)). The cells were incubated in calcium-free Krebs-Ringer solution containing $10 \mu \mathrm{M}$ EGTA to assure that no extracellular calcium would contribute to changes in cytosolic calcium.

The initial ratio had a mean value of 0.69 and was increased to a maximum mean value of 0.77 1-2 min after addition of thapsigargin. Then, it gradually decreased to a steady state level of a mean value of 0.65 during the following 5-6 min.

Figure 3(b) shows the effect of extracellular calcium on thapsigargin-primed differentiating neurons. There was a gradual decrease of the ratio from mean 0.67 to mean 0.63 during the initial incubation of the differentiating cells with thapsigargin in the absence of extracellular calcium. While the cells were incubated with thapsigargin, addition of calcium caused an immediate increase of the ratio to mean 0.73 within $2 \mathrm{~min}$. The increased calcium was either unchanged or moderately elevated during the last 8-11 min of incubation (Figure 3(b)).

3.2.4. Calcium-Induced Increase of Cytosolic Calcium in Differentiating Neurons Incubated in the Absence or Presence of Sodium. The differentiating cells were dye loaded in a calcium-containing solution. The extracellular dye was removed by repeated washing of the cells. They were then incubated for $10 \mathrm{~min}$ in a calcium-free medium in the absence or presence of sodium (Figure 4(a)). Addition of calcium caused a time-dependent, continuous increase of cytosolic calcium in cells incubated in sodium-free solution. In contrast, following an initial calcium increase, the cytosolic calcium concentration seemed to level off in cells incubated in the presence of sodium.

AUC (area under the curve) of the time-dependent changes in fluorescence intensity (excitation ratio $360 \mathrm{~nm} /$ $380 \mathrm{~nm}$ ) was significantly larger during calcium stimulation (12 min) when sodium was omitted from the incubation solution (Figure $4(\mathrm{~b}))(p<0.05)$. The fraction of cells with increased cytosolic calcium was calculated in each experiment (Figure 4(c)). Increased calcium in response to addition of calcium was observed in $86 \%$ and $70 \%$ of cells in the absence (A) or presence (B) of sodium, respectively $(p<0.05)$. In contrast, the spontaneous calcium increase in cytosol was not influenced by sodium (C, D). However, omission of sodium greatly enhanced the cytosolic calcium concentration expressed as AUC during the spontaneous 


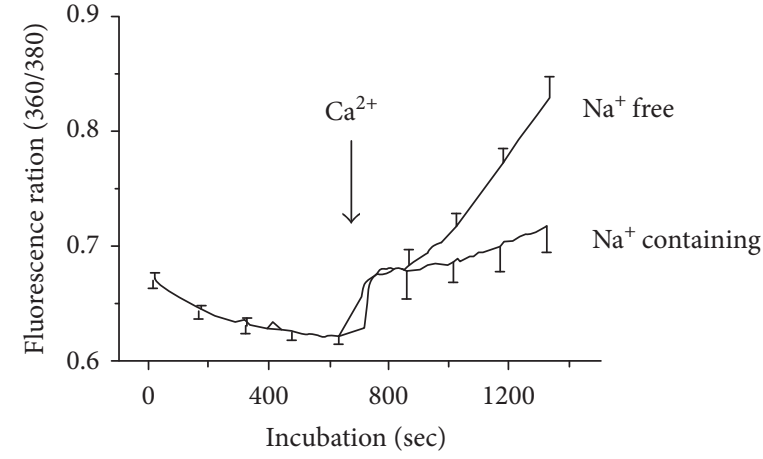

(a)

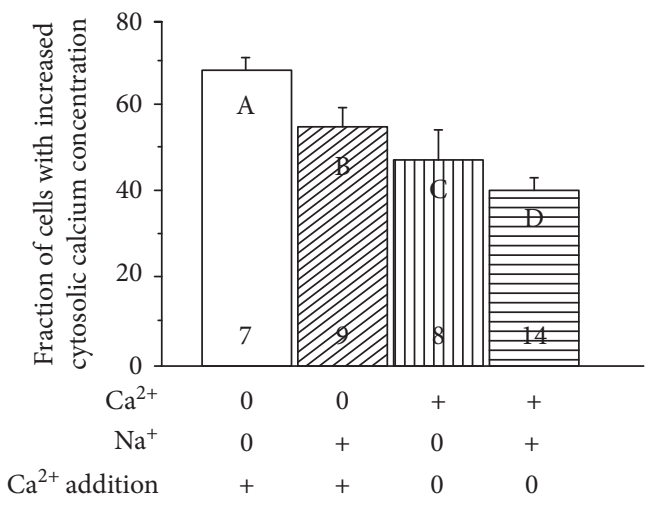

(c)

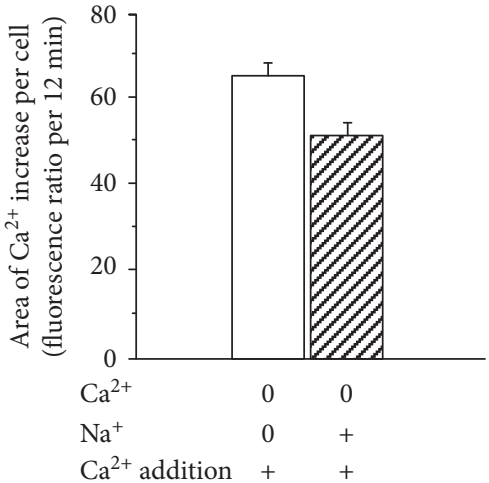

(b)

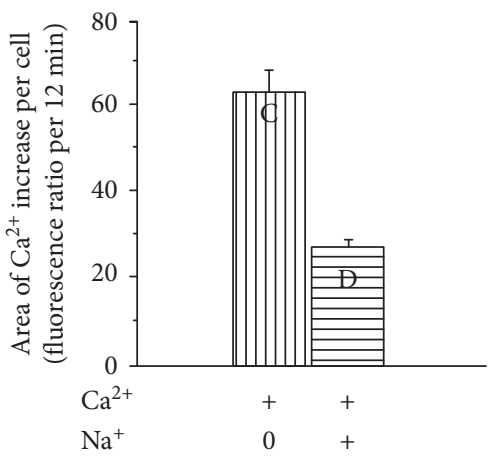

(d)

Figure 4: Calcium-induced increase of cytosolic $\mathrm{Ca}^{2+}$ in differentiating cells incubated in the absence or presence of $\mathrm{Na}^{+}$. After dye loading in the presence of $\mathrm{Ca}^{2+}$, cytosolic $\mathrm{Ca}^{2+}$ was monitored in cells incubated in a calcium-free medium with or without $\mathrm{Na}^{+}$and then $2 \mathrm{mM} \mathrm{Ca}^{2+}$ was added (arrow) (a). The area under the curve (AUC) of the effect of $\mathrm{Ca}^{2+}$ addition is shown (b). The fraction of cells that respond to the addition of $2 \mathrm{mM} \mathrm{Ca}^{2+}$ with increased cytosolic $\mathrm{Ca}^{2+}$ is shown (c). The cells were incubated in the absence and presence of $\mathrm{Na}^{+}$and then exposed to $2 \mathrm{mM} \mathrm{Ca}^{2+}\left((\mathrm{c})\right.$, columns A, B). Columns C and D show the fraction of cells with spontaneous Ca ${ }^{2+}$ increase in the absence and presence of $\mathrm{Na}^{+}$. AUC of the spontaneous $\mathrm{Ca}^{2+}$ increase is shown in columns C and D in Figure 4(d). GraphPad Prism4 was used to calculate AUC, expressed as fluorescence intensity (excitation ratio $360 \mathrm{~nm} / 380 \mathrm{~nm}$ ) per cell per $12 \mathrm{~min}$ (b) and 20 min (d), respectively. Mean value and SEM from 7 and 9 independent experiments (Figure 4(a)). Mean values and SEM from 296 cells and 270 cells incubated in the absence or presence of sodium, respectively (Figure 4(b)). Mean values and SEM from 7-14 experiments (Figure 4(c)) and 226 cells and 384 cells in Figure 4(d) (columns C and D, resp.). Column D in Figure 4(c) represents the data shown in Figure 2.

increase of cytosolic calcium (column C in Figure 4(d)) when compared to spontaneous calcium transients in cells incubated in sodium containing Krebs-Ringer solution $(p<0.0001)$ (column D in Figure 4(d)).

\subsubsection{Effect of Carbachol on Differentiating Neurons. Expres-} sion of genes encoding the cholinergic muscarinic receptors $\left(\mathrm{CHRM}_{1-5}\right)$ was confirmed using gene expression microarrays (data not shown).

Carbachol is a stable muscarinic agonist used to study the response of the differentiating stem cells to muscarinic Ach receptor activation [41]. There was an almost linear relation between the log dose of carbachol and the fraction of cells with calcium transients in each experiment (Supplemental Figure 2A). The cells were exposed to carbachol for $15 \mathrm{~min}$. Omission of extracellular calcium had no effect on the cellular response. However, the response was inhibited by pirenzepin $(10 \mu \mathrm{M})$, a muscarinic $\mathrm{M}_{1}$ receptor antagonist [40]. In order to quantify the intracellular calcium increase, we calculated AUC by use of GraphPad Prism 4 software. The baseline for the calculation was estimated by use of Origin 7.5. The AUC is expressed in arbitrary units as fluorescence intensity per $15 \mathrm{~min}$. Supplemental Figure 2B shows a doseresponse curve of the effect of carbachol on the mean value of AUC per cell of all the active cells. $10 \mu \mathrm{M}$ and $100 \mu \mathrm{M}$ carbachol caused a large increase of AUC, which was counteracted by $10 \mu \mathrm{M}$ pirenzepine. In calcium-free solution, there was almost no effect of carbachol.

3.3. Proliferating Midbrain-Derived Human Stem Cells. With the aim to investigate spontaneous calcium transients and calcium-regulating mechanisms, our analyses were extended to include proliferating stem cells. As mentioned in the general immunocytochemical characterization and shown in Figures 1 and 5, the immature stem cells expressed the proliferation marker Ki67 and the precursor cell marker nestin. Only few cells (less than $0.1 \%$ ) displayed spontaneous differentiation and expressed $\beta$-tub III. 

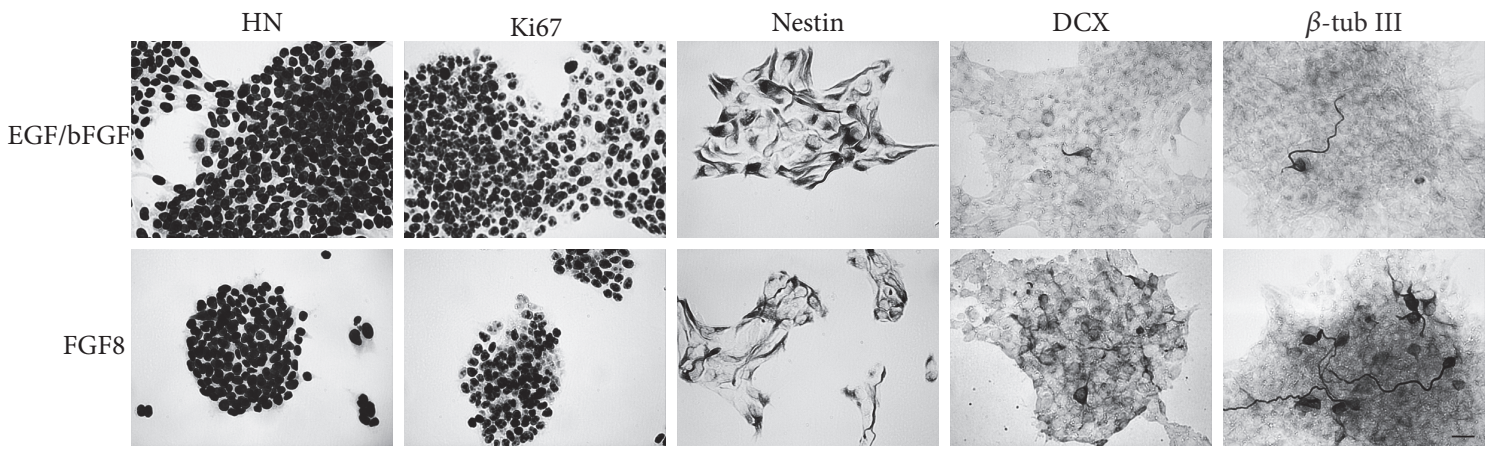

FIGURE 5: Immunocytochemical characterization of proliferating human midbrain-derived stem cells. Immunostaining of cells during, (1) standard propagation (upper panel) in a medium with epidermal growth factor (EGF) and basic fibroblast growth factor (bFGF) and (2) after removal of EGF/bFGF and one-day exposure to fibroblast growth factor 8 (FGF8) (lower panel), which represents the initial step of the induced neuronal differentiation (sequential addition of various factors, see Materials and Methods for details). To visualize all cells, cultures were immunostained using an antibody against human nuclei (HN). Almost all cells in both experimental groups expressed Ki67, a marker of dividing cells. Moreover, a very large proportion of the cells expressed the intermediate filament protein nestin, a marker of neural progenitor cells. Only very few cells had spontaneously differentiated into $\beta$-tubulin III- ( $\beta$-tub III-) positive or doublecortin(DCX-) positive immature neurons in the EGF/bFGF group, whereas some $\beta$-tub III-positive and DCX-positive neuronal cells were seen after short-term FGF8 treatment. Scale bar $=20 \mu \mathrm{m}$.

\subsubsection{Effect of Thapsigargin and Calcium on Proliferating} Stem Cells Incubated in a Calcium-Free Medium. Exposure of the cells to $2 \mu \mathrm{M}$ thapsigargin in a calcium-free medium induced a transient increase of cytosolic calcium in more than $2 / 3$ of the cells in two independent experiments (Supplemental Figure 3). The cells were incubated in a calcium-free Krebs-Ringer solution containing $10 \mu \mathrm{M}$ EGTA to assure that no extracellular calcium would contribute to changes in cytosolic calcium.

Stem cells were also primed with $2 \mu \mathrm{M}$ thapsigargin for $30 \mathrm{~min}$ in a calcium-free Krebs-Ringer solution. Addition of $2 \mathrm{mM}$ calcium (without thapsigargin) induced a calcium transient in seven independent experiments containing 332 cells that all responded with a calcium transient to the addition of calcium (Supplemental Figure 4). These experiments are thus similar to the experiments illustrated in Figure 3(a).

When the cells were loaded in the presence of calcium and incubated in a calcium-free medium with the addition of thapsigargin followed by the addition of calcium, two calcium transients were observed (Figure 6).

\subsubsection{Spontaneous Calcium Transients in Proliferating Stem} Cells. Representative calcium traces from cells were kept under six different experimental conditions (traces from five cells in each group) (Figure 7(a)). Spontaneous calcium transients were observed in $57 \%$ of cells incubated in KrebsRinger solution with $2 \mathrm{mM}$ calcium (Figure $7(\mathrm{~b})$; control sample; 1st bar). Omission of calcium in the incubation medium (Figure 7(b); 2nd bar) caused a significant decrease of the fraction of cells with calcium transients to $28 \%$ $(p<0.001)$. Depletion of intracellular calcium by loading of cells with Fluo-4 in the presence of $2 \mu \mathrm{M}$ thapsigargin in a calcium-free medium followed by incubation in a calciumfree medium further decreased the fraction of cells with calcium transients to $7 \%(p<0.05$, compared to samples in calcium-free solution) (Figure 7(b); 3rd bar).
Addition of $10 \mu \mathrm{M}$ carbachol to the incubation medium increased the fraction of cells with calcium transients to $54 \%$, and this was counteracted by adding $10 \mu \mathrm{M}$ pirenzepine to the incubation medium ( $p<0.05 ; 4$ th versus 5 th bar) (Figure 7(b)).

Incubation of cells in a sodium-free salt solution with calcium (Figure 7(b); 6th bar) significantly increased the fraction of cells with calcium transients to $81 \%(p<0.001$, compared to control value). Sodium was replaced by NMDG in order to maintain physiological osmolality.

\subsubsection{Pattern of Cytosolic Calcium Transients in Proliferating} Stem Cells. The appearance of the traces of control samples, samples from cells in a calcium-free medium as well as calcium-depleted cells, was similar to the trace observed with differentiated cells. Carbacholine-stimulated cells showed broad calcium transients, and the baseline calcium level gradually increased during the incubation in a sodiumfree medium.

\section{Discussion}

4.1. Differentiating Human Midbrain-Derived Stem Cells. Calcium signaling has essential roles in the development of the nervous system from neural induction to the proliferation, migration, and differentiation of neural cells [42-44].

We have observed spontaneous elevations of intracellular calcium concentrations (calcium transients) in human midbrain-derived stem cells undergoing neuronal differentiation (see Supplemental Figure 1 (video) and Figure 2). The calcium transients varied in rate and shape. The basal calcium level seemed to change according to the use of pump and calcium channel-active drugs used for the experiments (thapsigargin and ryanodine, resp.). The source of calcium for the calcium transients might be the extracellular calcium which enters the cytosol through calcium channels or 


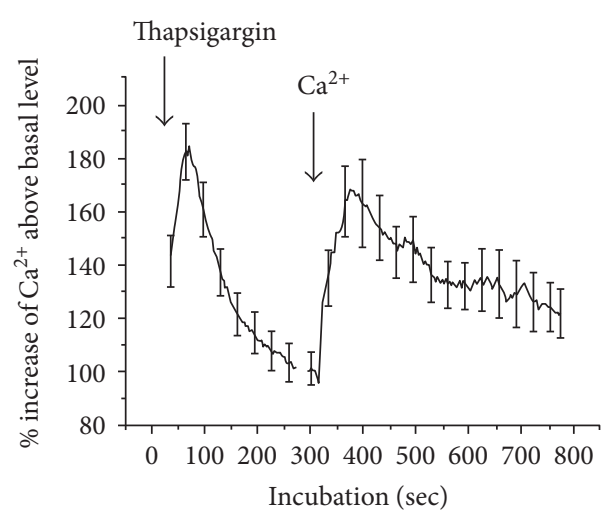

(a)

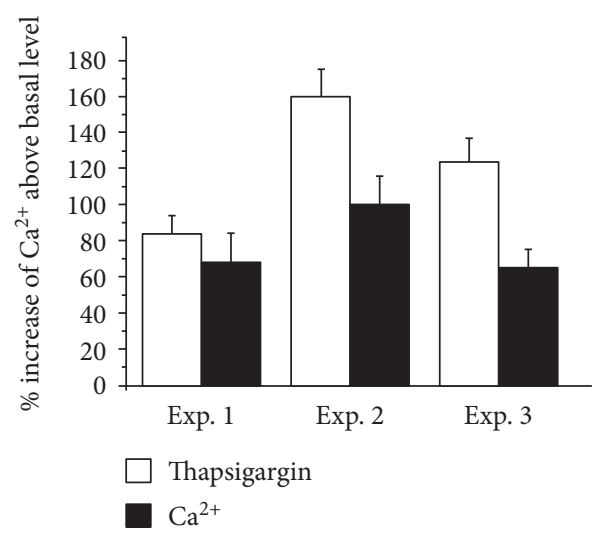

(b)

FIgURE 6: Effect of thapsigargin and calcium on proliferating stem cells incubated in a calcium-free medium. The cells were dye loaded and washed in a calcium-containing medium and then incubated in a calcium-free medium with $10 \mu \mathrm{M}$ EGTA. Thapsigargin $(2 \mu \mathrm{M}$, final concentration) was added after initiation of the incubation. After incubation for $300 \mathrm{sec}, 2 \mathrm{mM}$ calcium (final concentration) was added to the cells. The results from one of three independent experiments are shown (a). Abscissa: time of incubation (sec). Ordinate: intracellular calcium content. The fluorescence intensity was normalized to the level of the fluorescence intensity of untreated cells (100\%). Mean values and SEM from 31 cells. All the cells responded to the addition of thapsigargin and calcium. Peak values from all three experiments, after addition of thapsigargin (open column) and calcium (closed column) can be seen (b). Mean values and SEM from 31-64 cells. Taken together, 149 cells were studied in three independent experiments, and $98 \%$ of the cells responded to the addition of both thapsigargin and calcium.

intracellular calcium stores releasing calcium by opening $\mathrm{IP}_{3}$ - or ryanodine-sensitive channels.

4.1.1. Calcium Source to Spontaneous Calcium Transients in Differentiating Neurons. Removal of extracellular calcium greatly reduced the fraction of cells in each experiment with calcium transients demonstrating that the opening of plasma membrane calcium channels contributes to the calcium transients. Similar results were previously reported for human embryonic stem cell-derived neurons [28]. The number of transients per active cell decreased in the absence of external calcium but the remaining activity may indicate that calcium is also released from intracellular stores. This is in contrast to a previous report [28]. However, there was a change in the shape of the transients from narrow peaks in a calcium-free medium to broad and long-lasting calcium increases in calcium-depleted cells. This must be due to influx of calcium through yet uncharacterized calcium channels. Addition of thapsigargin decreased the transient activity, and the basal level of cytosolic calcium decreased gradually with time supporting the view that gradual store depletion invalidates the fine-tuning of the resting calcium concentration in the cytosol.

4.1.2. Effect of Thapsigargin on Differentiating Neurons. Thapsigargin specifically inhibits the endoplasmic calcium ATPase activity thus inhibiting the uptake of calcium into the endoplasmic reticulum [42]. Thapsigargin $(1 \mu \mathrm{M})$ has been shown to induce a substantial depletion of intracellular $\mathrm{Ca}^{2+}$ stores in a HeLa cell derivative [43]. In order to examine if differentiating human neural stem cells contain intracellular stores of calcium supplied with calcium pumps, cells were incubated with $2 \mu \mathrm{M}$ thapsigargin. The observed transient increase of cytosolic calcium (Figure 3(a)) seemed to indicate an inhibition of a thapsigargin-sensitive pump normally counteracting calcium leak from intracellular stores. Increase of cytosolic calcium caused by influx of extracellular calcium was not a likely explanation since the cells were incubated in calcium-free solution with $10 \mu \mathrm{M}$ EGTA.

\subsubsection{Store-Regulated Calcium Influx in Differentiating} Neurons. The concept of receptor-operated calcium entry was introduced more than 30 years ago [44]. It appeared to be a calcium-activated calcium release channel $[45,46]$. Recently, a likely sensor for the luminal calcium concentration in the endoplasmic reticulum has been identified [47-49], and a second protein, Orail or CRACM, was identified as a modulator of CRAC $\left(\mathrm{Ca}^{2+}\right.$ release-activated $\mathrm{Ca}^{2+}$ channels) or possibly the CRAC itself $[50,51]$. We observed a rather fast cytosolic calcium increase by addition of calcium to differentiating stem cells primed with thapsigargin in a calcium-free medium, which is considered to empty the intracellular calcium stores. This is likely to reflect an opening of store-operated calcium channels in the cells, which are considered an important mechanism of calcium entry into the cytosol [52]. However, we cannot exclude the possibility that the increased cytosolic calcium may result from opening of voltage-gated calcium channels. Recently, exposure of a neural stem cell line (hVM1) for $60 \mathrm{mM}$ potassium after 12 days of differentiation was shown to increase intracellular calcium in $9.5 \%$ of the cells, indicative of the development of excitability and calcium channels in the plasma membrane of these cells [53].

4.1.4. Effect of Ryanodine on Differentiating Neurons. Ryanodine binds to CRAC in the sarcoplasmic reticulum of 

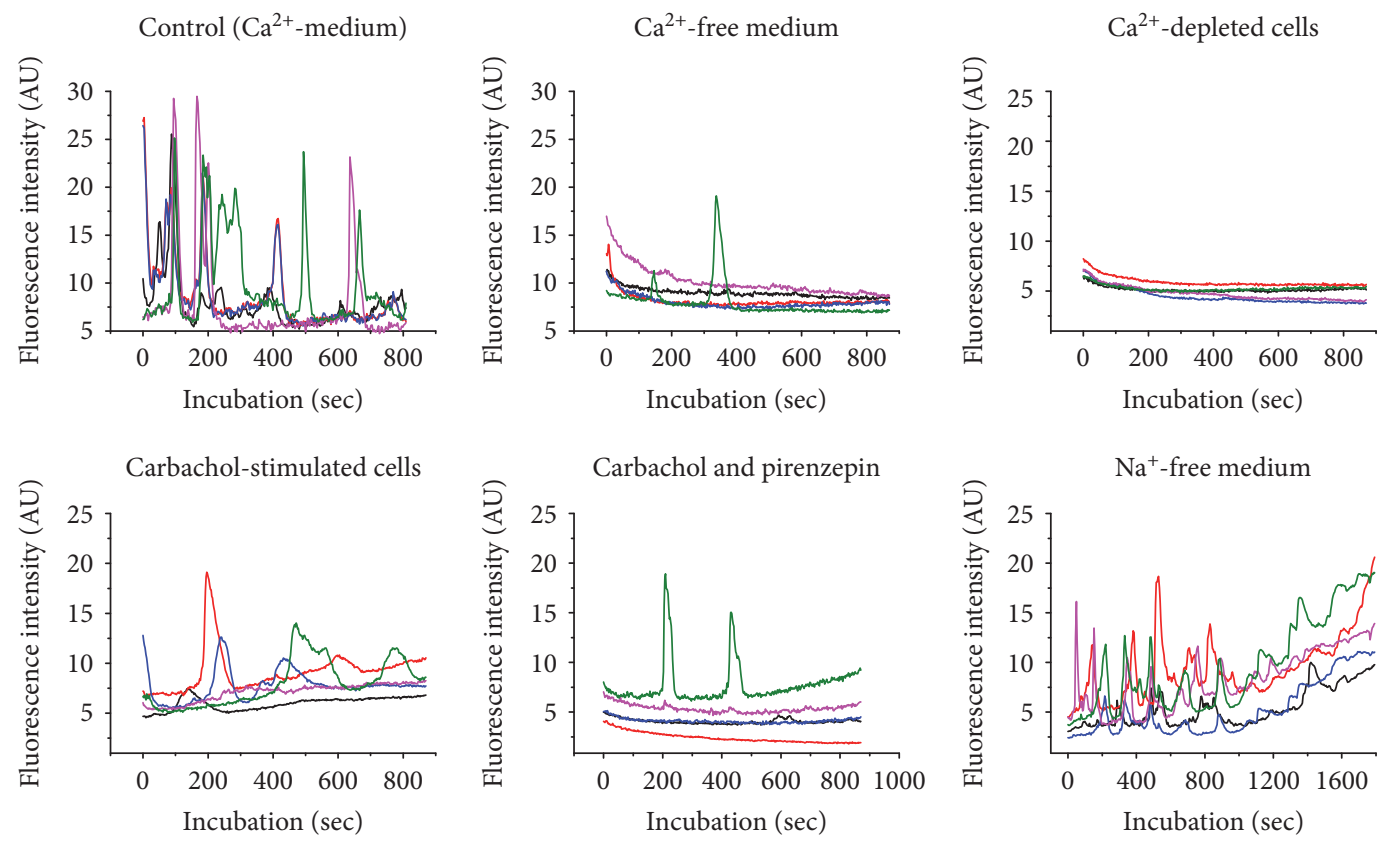

(a)

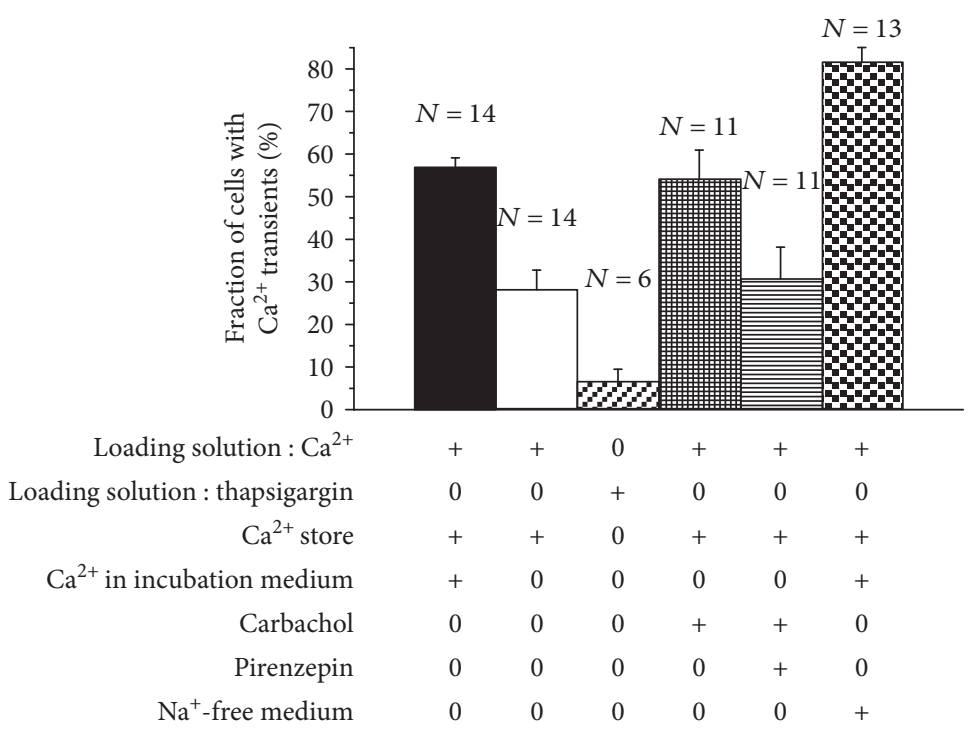

(b)

FIGURE 7: The fraction of proliferating cells with calcium transients during $15 \mathrm{~min}$ of incubation. Representative calcium traces from cells kept under six different experimental conditions (trace from five cells in each group) (a). The cells were loaded with $5 \mu \mathrm{M}$ Fluo-4. Calcium was present during the loading and the incubation procedures as indicated on the figure. Thapsigargin was used for depletion of calcium stores. Thapsigargin was present during the loading procedure. Carbachol and pirenzepin were present during the incubation. Sodiumfree solution was used only for the incubation. Mean values and SEM, 6-14 independent experiments (b).

cardiac and skeletal muscles as well as to the endoplasmic reticulum of various tissues $[54,55]$. These organelles constitute a major intracellular store of calcium in mammalian cells. Micromolar concentrations of ryanodine binds to a high-affinity site on the channels [56, 57] and locks the channel in a subconductance state with an open probability of unity [58-60]. Our observation of an increased number of calcium transients upon ryanodine treatment is in accordance with previous observations in rat chromaffin cells [61]. The time-dependent and gradual increase of cytosolic calcium in the presence of ryanodine may be explained by the development of the subconductance state of a ryanodine-sensitive calcium channel allowing the release of calcium to the cytosol. It may be speculated that the significant increase of the fraction of cells with calcium transients may be due to calcium-activated gating of channels in the plasma membrane or in the endoplasmic reticulum.

4.1.5. $\mathrm{Na}^{+} / \mathrm{Ca}^{2+}$ Exchanger in Differentiating Neurons. Maintenance of low-cytosolic calcium concentrations requires 
effective transport mechanisms for removal of calcium into the intracellular stores and across the plasma membrane to the extracellular medium. The plasma membrane $\mathrm{Ca}^{2+}$-ATPase (PMCA) pumps, and $\mathrm{Na}^{+} / \mathrm{Ca}^{2+}$ exchangers extrude $\mathrm{Ca}^{2+}$ to the outside, whereas the endoplasmic reticulum ATPase (SERCA) pumps sequester $\mathrm{Ca}^{2+}$ to the intracellular stores [2]. The turnover rate of the $\mathrm{Na}^{+} / \mathrm{Ca}^{2+}$ exchangers is considerable higher than that of the $\mathrm{Ca}^{2+}$-ATPase (PMCA) pumps while the affinity for $\mathrm{Ca}^{2+}$ is lower [62] indicating that $\mathrm{Na}^{+} / \mathrm{Ca}^{2+}$ exchanger activity is important for the regulation of cytosolic $\mathrm{Ca}^{2+}$. Our observation of a time-dependent increase of cytosolic calcium in cells incubated in the absence of sodium may indicate a reduction of $\mathrm{Ca}^{2+}$ extrusion capacity and loss of homeostasis. The cells were incubated in a $\mathrm{Ca}^{2}$ ${ }^{+}$-free solution for $10 \mathrm{~min}$ before the addition of calcium to the medium. This may contribute to lowering of the intracellular calcium stores and thus activation of the store-regulated calcium channels that allow influx of calcium upon the addition of calcium. Control experiments performed in the presence of sodium demonstrate that the effect of the calciumfree exposure was an increase of cytosolic calcium but to a lesser extent than that observed in a sodium-free medium. In accord, the AUC of the cells in a sodium-free medium was significantly larger than AUC from cells incubated in presence of sodium. We conclude that the plasma membrane of these cells contains an exchange mechanism for $\mathrm{Na}^{+}$and $\mathrm{Ca}^{2+}$. It may be speculated that the increase of the fraction of cells with calcium transients in sodium-free solution results from opening of store-regulated calcium channels.

4.1.6. Calcium Transients Induced by Carbacholine in Differentiating Neurons. Activation of muscarinic receptors $\mathrm{M}_{1}, \mathrm{M}_{3}$, and $\mathrm{M}_{5}$ is coupled to intracellular synthesis of inositol triphosphate $\left(\mathrm{IP}_{3}\right)$, which open calcium channels in the endoplasmic reticulum and allowing efflux of calcium into the cytosol $[63,64]$. We used the stable muscarinic agonist carbachol to study if the differentiating neurons responded to muscarinic activation [41] and then if the activation was transduced to intracellular release of calcium to the cytosol. The dose-dependent increase of the fraction of cells that respond to carbachol stimulation may indicate muscarinic receptor activation. This was supported by the observed inhibition by pirenzepine, which is considered a muscarinic $M_{1}$ receptor antagonist [41]. In accord, quantifying the calcium transients (AUC) demonstrates both the dose-dependence increase of the response to carbachol and the inhibition by pirenzepine. It may thus be reasoned that carbachol activates an $\mathrm{M}_{1}$ muscarinic receptor in the $\mathrm{PM}$ of differentiating neural stem cells. Control experiments in $\mathrm{Ca}^{2+}$-free solution support the idea that the increased cytosolic $\mathrm{Ca}^{2+}$ is due to $\mathrm{IP}_{3}$-sensitive channels in the endoplasmic reticulum allowing efflux of $\mathrm{Ca}^{2+}$ into the cytosol. Furthermore, while the calcium-free solution did not influence the fraction of cells with calcium transients, it influences the quantitative parameter (AUC) of the cytosolic calcium increase. A possible explanation could be that coordinated calcium supply from intracellular stores and the extracellular medium is a requirement for large and long-term increase of cytosolic calcium.
4.1.7. Possible Roles of Spontaneous Calcium Transients in Differentiating Neurons. We have previously investigated the effect of intracellular calcium transients on gene expression [65], which in immature cells might be a prerequisite for cell differentiation. Dolmetsch et al. [5] reported that intracellular calcium oscillations in T-lymphocytes increase both the efficacy and the information content of calcium signals that lead to gene expression and cell differentiation. Moreover, recent reports show that spontaneous Ca oscillations in human immature dendritic cells are linked to translocation of transcription factor NFAT (nuclear factor of activated T-cells) into the nucleus [66] and that endogenous calcium spike activity in Xenopus tropicalis regulates genetic pathways involved in neuronal development of transmitter specification [67]. We suggest that the spontaneous calcium transients that we have observed in our human midbrainderived stem cells may contribute to mechanisms involved in their differentiation.

4.1.8. Summary of Calcium Regulation in Differentiating Neurons. We have provided evidence for activity of intracellular calcium stores with sensitivity for thapsigargin and ryanodine, indicating the presence of endoplasmic reticulum ATPase (SERCA) pumps and ryanodine receptors. Furthermore, it is likely that our cells contain muscarinic $\mathrm{M}_{1}$ receptors in the plasma membrane that might initiate $\mathrm{IP}_{3}$ synthesis and thus activate $\mathrm{IP}_{3}$ receptors on the endoplasmic reticulum. Extrusion of calcium across the plasma membrane seems to occur by sodium-calcium exchange and influx of calcium by store-activated calcium channels. The spontaneous calcium transients are supplied by calcium from either the intracellular stores or the extracellular medium. Available calcium supply influences the pattern of activity. The quantitative largest calcium increase (AUC) seemed to require a coordinated calcium supply from both sources. Although it seems that these cells have developed the mechanisms necessary for control of calcium spiking as also reported for human mesenchymal stem cells, further experiments are necessary to evaluate the interplay between the mechanisms that lead to cytosolic calcium increase and decrease, respectively, as well as to elucidate a possible role of voltageactivated or receptor-activated calcium channels in the plasma membrane.

\subsection{Proliferating Human Midbrain-Derived Stem Cells}

4.2.1. Evidence for Calcium Stores and Store-Regulated Ion Channels in the Plasma Membrane of Proliferating Stem Cells. Thapsigargin is known to block a calcium ATPase, which supplies energy to reuptake calcium to intracellular stores of calcium. The observed calcium transients in a major fraction of the cells (Supplemental Figure 3) support the view that the proliferating stem cells do contain intracellular calcium stores. The effect of thapsigargin may be explained by a disturbing effect of thapsigargin on the balance between release and reuptake of calcium into the stores resulting in depletion of the stores for calcium. Depletion of calcium stores is known to activate store-regulated calcium channels in the plasma membrane. When the cells were primed with 
thapsigargin in a calcium-free medium, the subsequent incubation with calcium (Supplemental Figure 4) induced a calcium transient which is likely to be the result of opening of calcium channels in the plasma membrane in response to the depletion of the intracellular stores. This view is supported by the results shown in Figure 6 that thapsigargin releases calcium from the stores and this causes an influx of calcium.

\subsubsection{Calcium Supply to Spontaneous Calcium Transients in} Proliferating Stem Cells. We report spontaneous calcium transients in proliferating neural stem cells (Figures 7(a) and $7(\mathrm{~b}))$. More than $55 \%$ of the cells displayed spontaneous transients during the observation period. The cells were loaded with Fluo-4 in the presence of calcium in order to avoid depletion of intracellular calcium. Then, the cells were incubated in the presence of calcium. Omission of extracellular calcium caused a significant decrease of the fraction of cells with calcium transients to about half the value of the control sample. This may indicate that extracellular calcium contributes to the intracellular calcium transients. However, in the absence of external supply of calcium, there is still a substantial fraction of cells with calcium transients, which is almost abolished when the cells were pretreated with thapsigargin in a calcium-free medium. This treatment is likely to empty intracellular calcium stores, suggesting that these could be the calcium supplier for the spontaneous calcium transients.

We conclude that there are spontaneous calcium transients in neural stem cells during proliferation and that the calcium supply for the transients is mediated via both intracellular stores and calcium influx from the extracellular medium.

4.2.3. Calcium Transients in Proliferating Cells Induced by Carbachol. If the cells contain intracellular calcium stores, it is likely that they may respond to activation of plasma membrane receptors that produce inositol triphosphate. We have stimulated the cells with the acetylcholine analogue carbachol in a calcium-free medium and observed an increase of the fraction of cells with calcium transients compared to cells incubated in a calcium-free medium $(p<0.01)$. This effect was counteracted by pirenzepine, which is a selective inhibitor of $M_{1}$ acetylcholine receptors. These observations support the view that proliferating neural stem cells contain intracellular calcium stores and a muscarinic $M_{1}$ receptor in the plasma membrane. It is likely that carbachol activation induces synthesis of inositol triphosphate that releases calcium from the intracellular stores.

\subsubsection{Existence of a $\mathrm{Na}^{+} / \mathrm{Ca}^{2+}$ Exchanger in Proliferating} Stem Cells. The decrease of intracellular calcium following the peak value of the transients induced by thapsigargin (Supplemental Figure 3) could be due to removal of cytosolic calcium through efflux across the plasma membrane since reuptake to intracellular calcium stores is unlikely in the presence of thapsigargin. The mechanism of extrusion could be an exchange of intracellular calcium for extracellular sodium. We have incubated stem cells in the absence of sodium since in a sodium-free medium, the extrusion of calcium is abolished. This induced a significant increase of the fraction of cells with calcium transients compared to the control value $(p<0.001)$ as well as of the baseline calcium content. Thus, our observation supports the view that proliferating neural stem cells have developed a $\mathrm{Na}^{+} / \mathrm{Ca}^{2+}$ antiporter in the plasma membrane.

\section{Conclusion}

This is the first comparative report of spontaneous calcium transients in proliferating and differentiating human midbrain-derived stem cells that provides evidence for mechanisms that are likely to be involved. We propose that the observed spontaneous calcium transients may influence signaling pathways involved in stem cell proliferation, phenotypic differentiation, and maturation.

\section{Conflicts of Interest}

The authors declare that the research was conducted in the absence of any commercial or financial relationships that could be construed as a potential conflict of interest.

\section{Acknowledgments}

The expert technical assistance of Dorte Lyholmer and Annette Kragh Rasmussen is gratefully acknowledged. The authors thank Dr. Pia Jensen for the help with bioimaging. This research was supported by the Danish Parkinson Association, Grosserer M. Brogaard og Hustrus Mindefond, Hørslev Fonden, IMK Almene Fond, and Kirsten og Freddy Johansens Fond. Work at AMS laboratory was supported by grants from Cumunidad Autonóma Madrid (S2010BMD-2336) and Instituto Salud Carlos III (RETICS TerCel, RD12/0019/0013).

\section{References}

[1] M. J. Berridge, M. D. Bootman, and P. Lipp, "Calcium-a life and death signal," Nature, vol. 395, pp. 645-648, 1998.

[2] M. J. Berridge, P. Lipp, and M. D. Bootman, "The versatility and universality of calcium signalling," Nature Reviews Molecular Cell Biology, vol. 1, pp. 11-21, 2000.

[3] M. D. Bootman, T. J. Collins, C. M. Peppiatt et al., "Calcium signalling-an overview," Seminars in Cell \& Developmental Biology, vol. 12, pp. 3-10, 2001.

[4] R. E. Dolmetsch, R. S. Lewis, C. C. Goodnow, and J. I. Healy, "Differential activation of transcription factors induced by $\mathrm{Ca}^{2+}$ response amplitude and duration," Nature, vol. 386, pp. 855-858, 1997.

[5] R. E. Dolmetsch, K. Xu, and R. S. Lewis, "Calcium oscillations increase the efficiency and specificity of gene expression," Nature, vol. 392, pp. 933-936, 1998.

[6] Y. Gwack, S. Feske, S. Srikanth, P. G. Hogan, and A. Rao, "Signalling to transcription: Store-operated $\mathrm{Ca}^{2+}$ entry and NFAT activation in lymphocytes," Cell Calcium, vol. 42, pp. 145-156, 2007. 
[7] M. Oh-Hora, "Calcium signaling in the development and function of T-lineage cells," Immunological Reviews, vol. 231, pp. 210-224, 2009.

[8] S. A. Stricker, "Comparative biology of calcium signaling during fertilization and egg activation in animals," Developmental Biology, vol. 211, pp. 157-176, 1999.

[9] L. Santella, D. Lim, and F. Moccia, "Calcium and fertilization: the beginning of life," Trends in Biochemical Sciences, vol. 29, pp. 400-408, 2004.

[10] S. Miyazaki, "Thirty years of calcium signals at fertilization," Seminars in Cell \& Developmental Biology, vol. 17, pp. 233243, 2006.

[11] K. T. Jones, "Intracellular calcium in the fertilization and development of mammalian eggs," Clinical and Experimental Pharmacology \& Physiology, vol. 34, pp. 1084-1089, 2007.

[12] S. E. Webb and A. L. Miller, "Calcium signalling during embryonic development," Nature Reviews Molecular Cell Biology, vol. 4, pp. 539-551, 2003.

[13] E. Yanagida, S. Shoji, Y. Hirayama et al., "Functional expression of $\mathrm{Ca}^{2+}$ signaling pathways in mouse embryonic stem cells," Cell Calcium, vol. 36, pp. 135-146, 2004.

[14] M. Whitaker, "Calcium at fertilization and in early development," Physiological Reviews, vol. 86, pp. 25-88, 2006.

[15] M. Whitaker, "Calcium signalling in early embryos," Philosophical Transactions of the Royal Society of London Series B, Biological Sciences, vol. 363, pp. 1401-1418, 2008.

[16] D. C. Slusarski and F. Pelegri, "Calcium signaling in vertebrate embryonic patterning and morphogenesis," Developmental Biology, vol. 307, pp. 1-13, 2007.

[17] M. Whitaker and J. Smith, "Introduction. Calcium signals and developmental patterning," Philosophical Transactions of the Royal Society of London Series B, Biological Sciences, vol. 363, pp. 1307-1310, 2008.

[18] X. Cao and Y. Chen, "Mitochondria and calcium signaling in embryonic development," Seminars in Cell \& Developmental Biology, vol. 20, pp. 337-345, 2009.

[19] N. C. Spitzer, N. J. Lautermilch, R. D. Smith, and T. M. Gomez, "Coding of neuronal differentiation by calcium transients," BioEssays, vol. 22, pp. 811-817, 2000.

[20] P. Liljelund, J. G. Netzeband, and D. L. Gruol, "L-type calcium channels mediate calcium oscillations in early postnatal Purkinje neurons," The Journal of Neuroscience, vol. 20, pp. 7394-7403, 2000.

[21] J. C. Platel, A. Dupuis, S. Boisseau, M. Villaz, M. Albrieux, and J. Brocard, "Synchrony of spontaneous calcium activity in mouse neocortex before synaptogenesis," The European Journal of Neuroscience, vol. 25, pp. 920-928, 2007.

[22] A. Fabbro, B. Pastore, A. Nistri, and L. Ballerini, "Activityindependent intracellular $\mathrm{Ca}^{2+}$ oscillations are spontaneously generated by ventral spinal neurons during development in vitro," Cell Calcium, vol. 41, pp. 317-329, 2007.

[23] S. Sibilla, A. Fabbro, M. Grandolfo, P. D’Andrea, A. Nistri, and L. Ballerini, "The patterns of spontaneous $\mathrm{Ca}^{2+}$ signals generated by ventral spinal neurons in vitro show time-dependent refinement," The European Journal of Neuroscience, vol. 29, pp. 1543-1559, 2009.

[24] R. R. Resende, A. Adhikari, J. L. da Costa et al., "Influence of spontaneous calcium events on cell-cycle progression in embryonal carcinoma and adult stem cells," Biochimica et Biophysica Acta-Molecular Cell Research, vol. 1803, pp. 246-260, 2010.
[25] S. Kawano, S. Shoji, S. Ichinose, K. Yamagata, M. Tagami, and M. Hiraoka, "Characterization of $\mathrm{Ca}^{2+}$ signaling pathways in human mesenchymal stem cells," Cell Calcium, vol. 32, pp. 165-174, 2002.

[26] S. Kawano, K. Otsu, S. Shoji, K. Yamagata, and M. Hiraoka, " $\mathrm{Ca}^{2+}$ oscillations regulated by $\mathrm{Na}^{+}-\mathrm{Ca}^{2+}$ exchanger and plasma membrane $\mathrm{Ca}^{2+}$ pump induce fluctuations of membrane currents and potentials in human mesenchymal stem cells," Cell Calcium, vol. 34, pp. 145-156, 2003.

[27] S. Kawano, K. Otsu, A. Kuruma et al., "ATP autocrine/ paracrine signaling induces calcium oscillations and NFAT activation in human mesenchymal stem cells," Cell Calcium, vol. 39, pp. 313-324, 2006.

[28] J. P. Weick, M. Austin Johnson, and S. C. Zhang, "Developmental regulation of human embryonic stem cell-derived neurons by calcium entry via transient receptor potential (Trp) channels," Stem Cells, vol. 27, pp. 2906-2916, 2009.

[29] J. Ferreira-Martins, C. Rondon-Clavo, D. Tugal et al., "Spontaneous calcium oscillations regulate human cardiac progenitor cell growth," Circulation Research, vol. 105, pp. 764-774, 2009.

[30] S. Malmersjö, I. Liste, O. Dyachok, A. Tengholm, E. Arenas, and P. Uhlén, " $\mathrm{Ca}^{2+}$ and cAMP signaling in human embryonic stem cell-derived dopamine neurons," Stem Cells and Development, vol. 19, pp. 1355-1364, 2010.

[31] M. Yamashita, "Ion channel activities in neural stem cells of the neuroepithelium," Stem Cells International, vol. 2012, Article ID 247670, 6 pages, 2012.

[32] S. Malmersjö, P. Rebellato, E. Smedler et al., "Neural progenitors organize in small-world networks to promote cell proliferation," Proceedings of the National Academy of Sciences of the United States of America, vol. 110, pp. E1524-E1532, 2013.

[33] P. Morgan, R. Hübner, A. Rolfs, and M. J. Frech, "Spontaneous calcium transients in human neural progenitor cells mediated by transient receptor potential channels," Stem Cells and Development, vol. 22, pp. 2477-2486, 2013.

[34] C. Krabbe, E. Courtois, P. Jensen et al., "Enhanced dopaminergic differentiation of human neural stem cells by synergistic effect of Bcl- $\mathrm{x}_{\mathrm{L}}$ and reduced oxygen tension," Journal of Neurochemistry, vol. 110, pp. 1908-1920, 2009.

[35] C. Krabbe, S. T. Bak, P. Jensen et al., "Influence of oxygen tension on dopaminergic differentiation of human fetal stem cells of midbrain and forebrain origin," PLoS One, vol. 9, article e96465, 2014.

[36] E. T. Courtois, C. G. Castillo, E. G. Seiz et al., "In vitro and in vivo enhanced generation of human $\mathrm{A} 9$ dopamine neurons from neural stem cells by $\mathrm{Bcl}-\mathrm{X}_{\mathrm{L}}$," The Journal of Biological Chemistry, vol. 285, pp. 9881-9897, 2010.

[37] A. Villa, I. Liste, E. T. Courtois et al., "Generation and properties of a new human ventral mesencephalic neural stem cell line," Experimental Cell Research, vol. 315, pp. 1860-1874, 2009.

[38] I. Liste, E. García-García, C. Bueno, and A. Martínez-Serrano, "Bcl-XL modulates the differentiation of immortalized human neural stem cells," Cell Death and Differentiation, vol. 14, pp. 1880-1892, 2007.

[39] Y. Ogawa, "Role of ryanodine receptors," Critical Reviews in Biochemistry and Molecular Biology, vol. 29, pp. 229-274, 1994.

[40] G. Stutzmann and M. Mattson, "Endoplasmic reticulum $\mathrm{Ca}^{2+}$ handling in excitable cells in health and disease," Pharmacological Reviews, vol. 63, pp. 700-727, 2011. 
[41] J. Uwada, A. S. M. Anisuzzaman, A. Nishimune, H. Yoshiki, and I. Muramatsu, "Intracellular distribution of functional $\mathrm{M}_{1}$-muscarinic acetylcholine receptors in N1E-115 neuroblastoma cells," Journal of Neurochemistry, vol. 118, pp. 958-967, 2011.

[42] O. Thastrup, P. J. Cullen, B. K. Drøbak, M. R. Hanley, and A. P. Dawson, "Thapsigargin, a tumor promoter, discharges intracellular $\mathrm{Ca} 2+$ stores by specific inhibition of the endoplasmic reticulum Ca2(+)-ATPase," Proceedings of the National Academy of Sciences of the United States of America, vol. 87, pp. 2466-2470, 1990.

[43] P. Uhlén, N. Fritz, E. Smedler, S. Malmersjö, and S. Kanatani, "Calcium signaling in neocortical development," Developmental Neurobiology, vol. 75, pp. 360-368, 2015.

[44] A. B. Toth, A. K. Shum, and M. Prakriya, "Regulation of neurogenesis by calcium signaling," Cell Calcium, vol. 59, pp. 124-134, 2016.

[45] M. Hoth and R. Penner, "Depletion of intracellular calcium stores activates a calcium current in mast cells," Nature, vol. 355, pp. 353-356, 1992.

[46] A. B. Parekh and J. W. Putney Jr, "Store-operated calcium channels," Physiological Reviews, vol. 85, pp. 757-810, 2005.

[47] C. Peinelt, M. Vig, D. L. Koomoa et al., "Amplification of CRAC current by STIM1 and CRACM1 (Orai1)," Nature Cell Biology, vol. 8, pp. 771-773, 2006.

[48] S. L. Zhang, Y. Yu, J. Roos et al., "STIM1 is a $\mathrm{Ca}^{2+}$ sensor that activates CRAC channels and migrates from the $\mathrm{Ca}^{2+}$ store to the plasma membrane,” Nature, vol. 437, pp. 902-905, 2005.

[49] S. L. Zhang, A. V. Yeromin, X. H. Zhang et al., "Genome-wide RNAi screen of $\mathrm{Ca}^{2+}$ influx identifies genes that regulate $\mathrm{Ca}^{2+}$ release-activated $\mathrm{Ca}^{2+}$ channel activity," Proceedings of the National Academy of Sciences of the United States of America, vol. 103, pp. 9357-9362, 2006.

[50] M. Vig, C. Peinelt, A. Beck et al., "CRACM1 is a plasma membrane protein essential for store-operated $\mathrm{Ca}^{2+}$ entry," Science, vol. 312, pp. 1220-1223, 2006.

[51] S. Feske, Y. Gwack, M. Prakriya et al., "A mutation in Orail causes immune deficiency by abrogating CRAC channel function," Nature, vol. 441, pp. 179-185, 2006.

[52] A. B. Parekh, "Functional consequences of activating storeoperated CRAC channels," Cell Calcium, vol. 42, pp. 111121, 2007.

[53] J. Tønnesen, E. G. Seiz, M. Ramos, O. Lindvall, A. MartinezSerrano, and M. Kokaia, "Functional properties of the human ventral mesencephalic neural stem cell line hVM1," Experimental Neurology, vol. 223, pp. 653-656, 2010.

[54] D. J. Jenden and A. S. Fairhurst, "The pharmacology of ryanodine," Pharmacological Reviews, vol. 21, pp. 1-25, 1969.

[55] L. Hymel, M. Inui, S. Fleischer, and H. Schindler, "Purified ryanodine receptor of skeletal muscle sarcoplasmic reticulum forms $\mathrm{Ca} 2+$-activated oligomeric $\mathrm{Ca} 2+$ channels in planar bilayers," Proceedings of the National Academy of Sciences of the United States of America, vol. 85, pp. 441445, 1988.

[56] F. A. Lattanzio, R. G. Schlatterer, M. Nicar, K. P. Campbell, and J. L. Sutko, "The effects of ryanodine on passive calcium fluxes across heavy and light sarcoplasmic reticulum and transverse tubular membranes from rabbit fast twitch skeletal muscle and sarcoplasmic reticulum membranes from canine myocardium," The Journal of Biological Chemistry, vol. 262, pp. 2711-2718, 1987.
[57] R. Bull, J. J. Marengo, B. A. Suárez-Isla, P. Donoso, J. L. Sutko, and C. Hidalgo, "Activation of calcium channels in sarcoplasmic reticulum from frog muscle by nanomolar concentrations of ryanodine," Biophysical Journal, vol. 56, pp. 749-756, 1989.

[58] E. Rousseau, J. S. Smith, and G. Meissner, "Ryanodine modifies conductance and gating behavior of single $\mathrm{Ca} 2+$ release channel," The American Journal of Physiology, vol. 253, pp. 364-368, 1987.

[59] S. Fleischer, E. M. Ogunbunmi, M. C. Dixon, and E. A. Fleer, "Localization of $\mathrm{Ca} 2+$ release channels with ryanodine in junctional terminal cisternae of sarcoplasmic reticulum of fast skeletal muscle," Proceedings of the National Academy of Sciences of the United States of America, vol. 82, pp. 7256-7259, 1985.

[60] G. Meissner, "Ryanodine receptor/Ca2+ release channels and their regulation by endogenous effectors," Annual Review of Physiology, vol. 56, pp. 485-508, 1994.

[61] P. D'Andrea, D. Zacchetti, J. Meldolesi, and F. Grohovaz, "Mechanism of $[\mathrm{Ca} 2+]$ i oscillations in rat chromaffin cells. Complex $\mathrm{Ca}(2+)$-dependent regulation of a ryanodinesensitive oscillator," The Journal of Biological Chemistry, vol. 268, pp. 15213-15220, 1993.

[62] M. P. Blaustein and W. J. Lederer, "Sodium/calcium exchange: its physiological implications," Physiological Reviews, vol. 79, pp. 763-854, 1999.

[63] C. C. Felder, "Muscarinic acetylcholine receptors: signal transduction through multiple effector," The FASEB Journal, vol. 9, pp. 619-625, 1995.

[64] M. P. Caulfield, "Muscarinic receptors-characterization, coupling and function," Pharmacology \& Therapeutics, vol. 58, pp. 319-379, 1993.

[65] E. García-García, M. J. Pino-Barrio, L. López-Medina, and A. Martínez-Serrano, "Intermediate progenitors are increased by lengthening of the cell cycle through calcium signaling and p53 expression in human neural progenitors," Molecular Biology of the Cell, vol. 23, pp. 1167-1180, 2012.

[66] M. Vukcevic, F. Zorzato, G. Spagnoli, and S. Treves, "Frequent calcium oscillations lead to NFAT activation in human immature dendritic cells," The Journal of Biological Chemistry, vol. 285, pp. 16003-16011, 2010.

[67] K. W. Marek, L. M. Kurtz, and N. C. Spitzer, “cJun integrates calcium activity and $t l x 3$ expression to regulate neurotransmitter specification," Nature Neuroscience, vol. 13, pp. 944-950, 2010.

[68] S. Malmersjö, P. Rebellato, E. Smedler et al., "Neural progenitors organize in small-world networks to promote cell proliferation," Proceedings of the National Academy of Sciences, vol. 110, pp. E1524-E1532, 2013. 

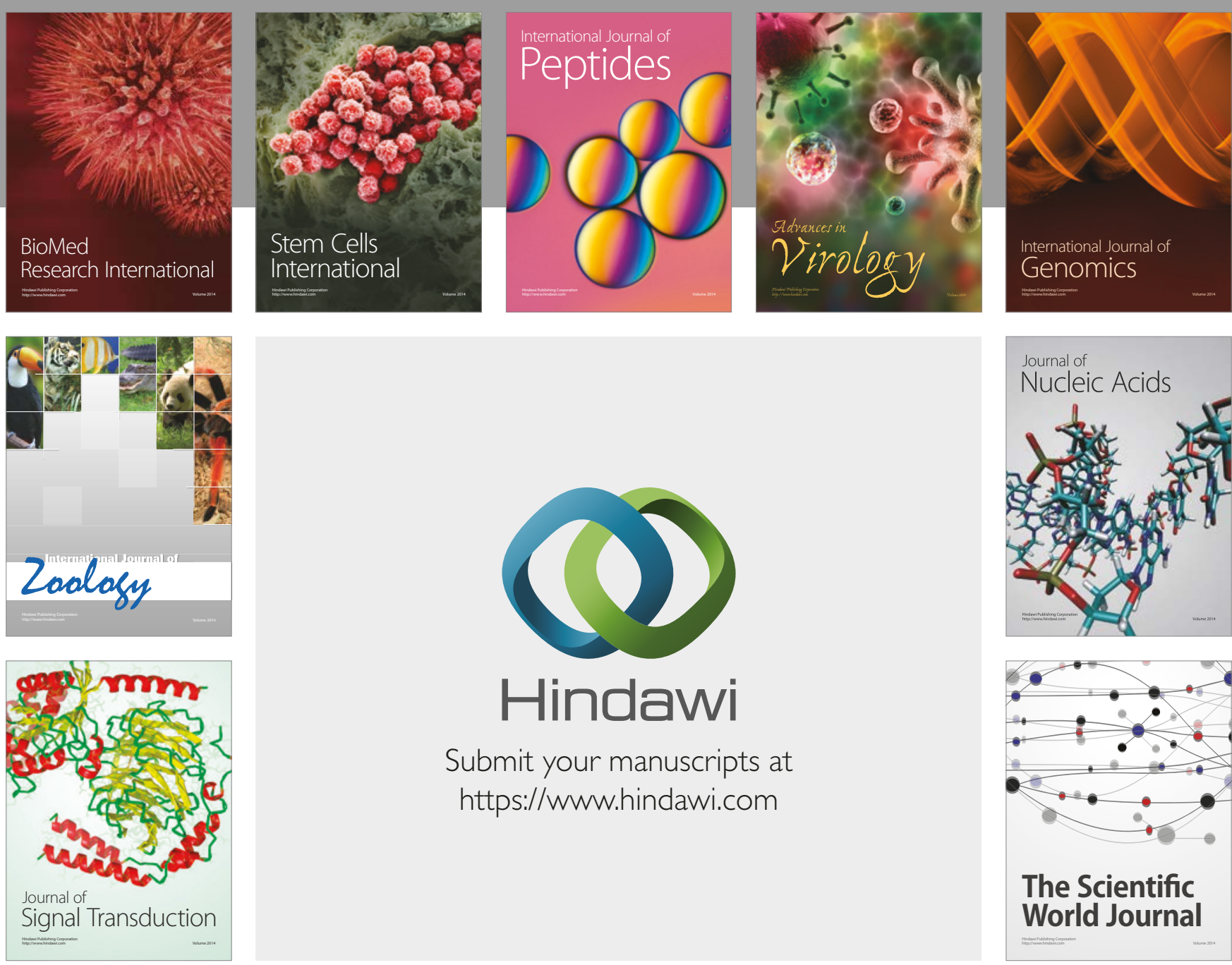

Submit your manuscripts at

https://www.hindawi.com
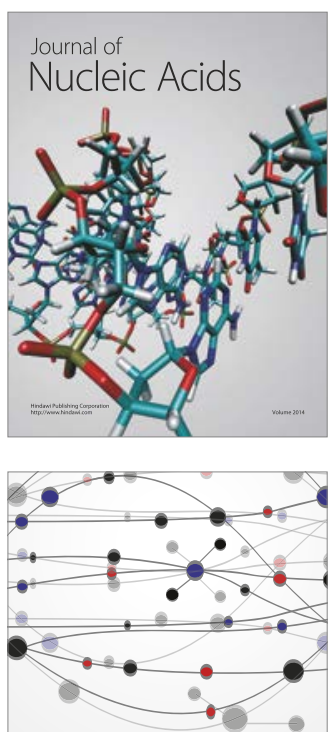

The Scientific World Journal

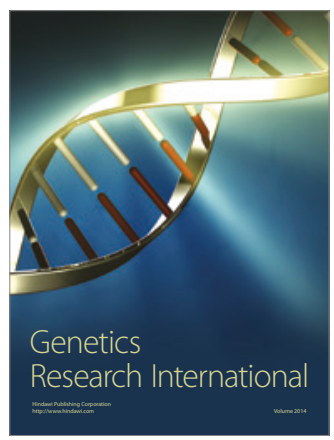

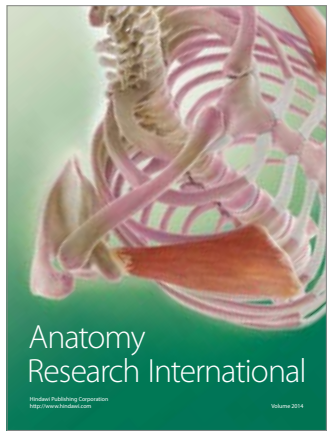

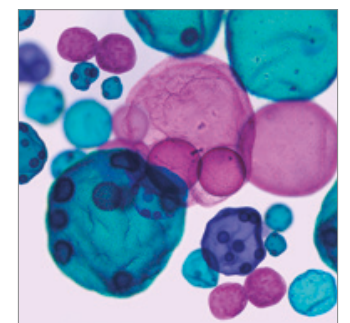

International Journal of Microbiology
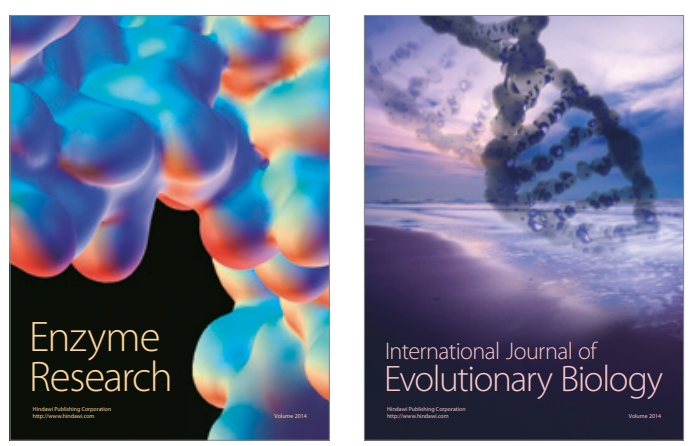
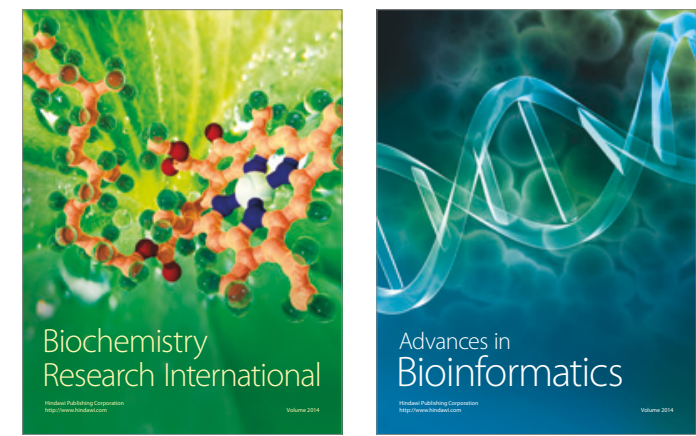

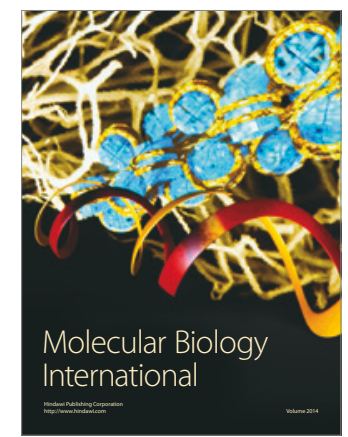

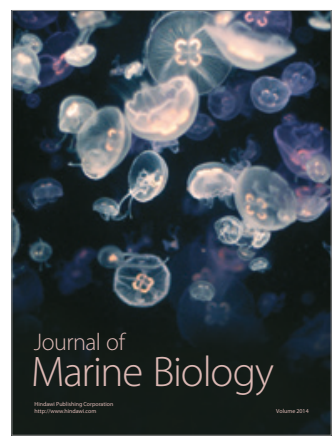

